\title{
Training Model of English Creative Talents under Language of Economics Perspective
}

\author{
Lina $\mathrm{Ma}^{1, \mathrm{a}^{*}}$ \\ ${ }^{1}$ School of Foreign Language, Zhengzhou University SIAS International College, Zhengzhou 451100, \\ China \\ aemail: linama1982@126.com
}

Keywords: Perspective of Economics of Language; Local colleges and universities; Business English; School-enterprise cooperation; Training mode.

\begin{abstract}
With the development of market economy and accelerated economic globalization, especially in the context of language training model Economics Business English Talents many universities started from a single training mode of school-enterprise cooperation to transition and change. Many local colleges and universities trained people will continually delivered to local businesses to not only meet local demand for business professionals, to a large extent the liberation and development of the local economy. Local talent based on the needs, whether it is from the arrangements and change course, or on the reform of teaching methods and teachers, and all around the direction of the school-enterprise cooperation and constantly improve the overall quality of talent, not only in order to achieve its fundamental purpose the rapid development of local colleges and universities, from a longer-term perspective in order to achieve sustainable development of the local economy.
\end{abstract}

\section{Introduction}

A wide range of subjects the language of economics, including linguistics, economics and education [1-3]. Language in modern society the role can not be ignored, the language itself is a form of capital, it can convert the cost of money, interest, or even the supreme honor; the value of the first language developed on the basis of a second language it better, and it has evolved into an investment, plays a different role in the current economic development of society [4]. The language of economics university language classes for professional development has a very high leading role [5]. Cultivation of College Personnel inseparable social demand for the type of talent, especially English professional development, which affected not only by international locales, and more importantly, the English language economy, whether in the political, economic, or social development fields have a position can not be ignored [6].

Now a lot of English talent training colleges have formed a fixed pattern. Development of the language of economics is no longer a single culture, but rather reflects more demand, more consideration to the needs of society and development. In particular, and economic development-related business English major, but also by a lot of companies and enterprises of all ages $[7,8]$. In the context of large-scale international development, has become a second language among the economic, social and cultural development of important communication tool [9].

As the most dynamic branch of ESP, Business English from a simple communication tool into language survival skills, because of its cross-cutting nature of the subject complex features and broad application prospects in line with the needs of society in recent years, domestic universities have opened business English courses to expand non-English majors become a popular choice. Business English courses but has just started to expand, current teaching neither former example, the lack of targeted educational materials and courseware, teaching widespread targeting is not clear, the content and methods of teaching basic English and College identical, students' interest in learning and the initiative is not enough, out of touch with the school and other issues, so how school-based, business English teaching model to develop a cost-effective, is a serious problem. 


\section{Task experience model}

Student demand for business English courses and earnings forecasts; non-English majors to experience mission mode is recognized and accepted; and whether the job experience different model can effectively improve students' academic performance [10].

In the Business English courses, is the author of the study Universities 2012 elective office in the course of expanding non-English majors, with an average age of 19.7 years, commerce, medicine, the number of channels, textiles, grammar, biochemical, electrical and mechanical from hospital Department of the profession involving text, science, engineering and other disciplines.

The main tool used in this study is to expand the business English curriculum expectations questionnaire (hereinafter referred to as the "expected Questionnaire") and pattern recognition tasks Experience Survey Scale (hereinafter referred to as "approved Scale"). According to the former Business English courses questionnaire elective and non-English majors Fact Sheet Adapted by 10 multiple-choice questions and an enclosed open-ended questions composition; Business English elective for students to understand the purpose of research and learning needs demand. The latter includes 15 items, Likert 5 subscale scores for each question item 5-point scale $(1=$ strongly disagree, $5=$ totally agree). To test the scale construct validity and reliability, the author first test measured students' organization, the data obtained by analysis SPSS 17. 0, and scales were KMO measure and Bartlett test of sphericity. The results show, KMO value is 0.771 , significant probability Bartlett test of sphericity close to 0 (Chi - Square $=826.674, \mathrm{df}=66, \mathrm{p}=000<0.01)$, described the scale test data suitable for factor analysis .

Using principal component analysis by varimax rotation factor analysis of the data, according to the factor structure scree plot and the binding characteristics of value assumptions and ideas, clustered into 12 questions of three factors with eigenvalues greater than 1 (see Table 1, 3 a question do not meet the statistical requirements, so it is removed).

Table 1. Questions of three factors with eigenvalues greater

\begin{tabular}{c|c|c|c|c|c|c}
\hline \multirow{2}{*}{ Serial Number } & \multicolumn{3}{|c|}{ Initial Eigenvalues (\%) } & \multicolumn{3}{c}{ Extraction of sum of squares loaded (\%) } \\
\cline { 2 - 7 } & Total & Variance & Accumulation & Total & Variance & Accumulation \\
\hline 1 & 5.693 & 47.442 & 47.442 & 5.693 & 47.442 & 47.442 \\
\hline 2 & 1.382 & 11.517 & 59.958 & 1.382 & 11.517 & 58.958 \\
\hline 3 & 1.265 & 10.539 & 69.498 & 1.265 & 10.539 & 69.948 \\
\hline
\end{tabular}

These three factors are named as "the feasibility of recognition," "adaptive recognition" and "validity of acceptance" (see Table 2). Factor loadings of all items in more than 0.547 greater than the acceptable value of 0.40 , the cumulative rate of $69.498 \%$ variance explained, scales well explained variance. Therefore, the scale construct validity is good. Cronbach's $\alpha$ value of the three factors were $0.744,0.753,0.846$, internal consistency coefficient was 0.889 , indicating that the scale has high reliability, a more comprehensive overview of the research data features, meet the test requirements.

From the point of view of economics of language teaching is good or bad reflection of the level of investment value. Career development and future demand Business English teaching is student as a starting point, is long-term investment; dynamic and timely evaluation of students with a guide investment, promotion and incentives. Especially if the evaluation linked to the vital interests of the individual, the formation of more intrinsic motivation, promote investment and improve student teaching income. In this study, we attach great importance to promoting the formative evaluation of the role of human capital investment, mainly to assess student performance assessment method (including learning progress, logs, work, group activities and group records evaluation reports), and every month in the "Business English updated performance "experience on the platform, it will not only allow students to see their return on learning, continue to increase investment, but also to stimulate students' interest in investing in the other, actively involved in learning and teamwork activities. 
Table 2. The feasibility of recognition," "adaptive recognition" and "validity of acceptance"

\begin{tabular}{|c|c|c|c|}
\hline Survey Items & Items & $\begin{array}{l}\text { Mean } \\
\text { Value }\end{array}$ & $\begin{array}{l}\text { Standard } \\
\text { Deviation }\end{array}$ \\
\hline \multirow{3}{*}{$\begin{array}{l}\text { Feasibility of } \\
\text { the } \\
\text { recognition }\end{array}$} & $\begin{array}{l}\text { Through experience and practice task gradually } \\
\text { master the business English is feasible. }\end{array}$ & 3.64 & 0.519 \\
\hline & $\begin{array}{l}\text { A virtual company helps me to understand the } \\
\text { basic process of business activities }\end{array}$ & 4.07 & 0.800 \\
\hline & $\begin{array}{l}\text { Different simulation tasks helps improve the } \\
\text { ability of using English. }\end{array}$ & 3.81 & 0.787 \\
\hline \multirow{4}{*}{$\begin{array}{l}\text { Adaptive } \\
\text { recognition }\end{array}$} & $\begin{array}{l}\text { I like the way to experience the business activities } \\
\text { by finishing some task. }\end{array}$ & 3.81 & 0.730 \\
\hline & $\begin{array}{l}\text { Different forms of activities can stimulate my } \\
\text { interest in learning business English. }\end{array}$ & 3.79 & 0.574 \\
\hline & $\begin{array}{l}\text { Simulation departments do tasks can promote the } \\
\text { communication and interactionbetween students. }\end{array}$ & 3.87 & 0.921 \\
\hline & $\begin{array}{l}\text { The new teaching mode can harmonious } \\
\text { relationship between teachers and students and } \\
\text { relax classroom atmosphere. }\end{array}$ & 3.80 & 0.878 \\
\hline \multirow{5}{*}{$\begin{array}{l}\text { Effective } \\
\text { recognition }\end{array}$} & $\begin{array}{l}\text { To complete the class activities as a group } \\
\text { effectively increases the chances of mine to use } \\
\text { English }\end{array}$ & 3.90 & 0.790 \\
\hline & Group cooperation reduces my anxiety. & 3.62 & 0.890 \\
\hline & $\begin{array}{l}\text { Simulate the department to complete the task } \\
\text { enhanced my communication and presentation } \\
\text { skills. }\end{array}$ & 3.70 & 0.750 \\
\hline & $\begin{array}{l}\text { The comprehensive evaluation of the new teach } \\
\text { mode reflect my efforts objectively. }\end{array}$ & 3.88 & 0.758 \\
\hline & $\begin{array}{l}\text { I think teaching effectof business English course } \\
\text { meet my expectations. }\end{array}$ & 3.63 & 0.521 \\
\hline
\end{tabular}

To test the effect of the teaching mode, the school also uses Business English final exam scores as a tool and independent samples $\mathrm{T}$ test. Taking into account the existence of a subjective scoring system for business writing questions uncertainties, using business English test scores from the second semester exam experimental class and control class machine readable objective questions results. The questions mainly on the part of the students' business English common terminology and vocabulary, reading skills, and business style business disciplines basic knowledge to grasp the situation, out of 85 points, exam results mean 63.27 points.

Teaching students to experience concern inner experience, the student body in a positive experience obtained in the utility (satisfaction) directly, in order to increase earnings and continue to invest in (learning) in pursuit of utility maximization, while teaching around the plurality of analog tasks step by step expand, in the teaching process to maximize active involvement of students, teachers teaching effectiveness increases, effective and efficient teaching and even teaching, real win-win. Therefore, the combination of both help to increase the effectiveness of teaching and learning, improve teaching business English input-output ratio in the inevitable choice of teaching methods. This study therefore attempts to practice serving the University College of Business English teaching experience in task mode to explore the feasibility and effectiveness of the model from the theory and practice. 


\section{Results and discussion}

"Expected Survey" data shows that most of the subjects studied business English showed the desire and motivation purely economic incentives, investment depends on the enthusiasm of the expected return. This verifies the Chiswick \& Miller, etc. 3E theory that economic motivation is an important factor in obtaining the language of capital, mainly by the needs of learners of English market value (employment) and non-market values (employment, education, promotion, etc.) of the impact of the expected benefits, such as access to the corresponding certificate English exam (direct benefits), to find the ideal position to get a higher income or more opportunities for advancement and other (indirect benefits).

According to "anticipate the investigation," more than 65\% of the subjects (148) Business English elective reasons or that it is interested in the future of the employment useful [such as "helps to study abroad and foreign companies to enter the job in the future," or " can improve business communication on the foreign language skills "(to improve the employability and competitiveness)], and that this course" for all students enrolling in "the proportion rose from $29 \%$ in the first semester to the second semester of $38 \%$, indicating a growing the more subjects begin to understand business English electives so more rational, more practical purpose. In fact, more than $61 \%$ of the survey subjects expressed the intention Business English Band.

As a follow-up college English courses, Business English and University Basic English is quite different, mainly reflected in three aspects: 1) Business English terminology and vocabulary as well as reading and writing skills for business style; 2) business concept, business processes and other business subject basics; 3) business practices, mainly involving various types of business communications (telephone, telex, e-mail) expression practice, international business environment in real case studies.

Table 3. The task of teaching experience model experiment

\begin{tabular}{|c|c|c|c|c|c|c|}
\hline Major & Class & Number & Average & $\begin{array}{l}\text { Standard } \\
\text { Deviation }\end{array}$ & Tvalue & DOF \\
\hline \multirow{2}{*}{ Business majors } & $A$ & 61 & 69.54 & 6.00 & \multirow{2}{*}{3.175} & \multirow{2}{*}{116} \\
\hline & B & 57 & 66.81 & 7.41 & & \\
\hline \multirow{2}{*}{ Non-business majors } & $\mathrm{C}$ & 52 & 63.37 & 7.92 & \multirow{2}{*}{2.384} & \multirow{2}{*}{102} \\
\hline & $\mathrm{D}$ & 52 & 60.42 & 8.94 & & \\
\hline Business majors & $A$ & 61 & 69.54 & 6.00 & \multirow{2}{*}{4.871} & \multirow{2}{*}{111} \\
\hline Non-business majors & $\mathrm{C}$ & 52 & 63.37 & 7.92 & & \\
\hline
\end{tabular}

Experimental class subjects and parallel control classes student achievement differences, and Professional \& Business Studies Major non-commercial experimental class subjects of the average difference of more than 6 points, a significant difference. Through classroom observations and interviews after school we learned: As a business closely related to English and professional future, the number of business school students apply for far more than the proportion of non-BEC Business Studies students, so learning initiative stronger business spending after-school learning English time and effort on non-business school students about twice or more. Thus, the future demand for professional and vocational students have a great role in promoting.

Statistical data from Table 3, the task of teaching experience model experiment has achieved good results. Although the expansion of the school curriculum is all students in the Class of independent is difficult to select the number of two, professional, English level equivalent to the real "parallel classes" as do the comparative analysis of the results of the pretest and posttest differences in the experimental group and the control group; however, on classroom observations and test results of the author of the first semester: all students at the beginning of the semester on business vocabulary, business quiz test performance roughly, there was no significant difference (in fact, even the business school students but also to the only junior business Studies courses opened), so students at the 
university comparable business English courses. Students starting in 2012 these three aspects (especially business English common terminology and vocabulary, reading skills, and business style business disciplines basics aspect) of roughly the same level there is no significant difference.

\section{Conclusions}

With the development of economic globalization, the social demand for "professional + English" compound talents surge, but in colleges and universities develop and supply and social demand for such talent there is a big gap between the reality and the resulting gap portion precisely because of inefficient teaching college English. The results of this study have in college English teaching inspiration. Not only to expand the program "individualized" and was "teaching because of the need" in order to truly meet the individual needs of college students, promoting investment and encouraging students to obtain effective teaching. Facing severe competition and development pressures, only market-oriented universities, college English teaching resources to optimize the configuration, in order to improve the English investment income, establish a "professional + English" compound talents training mode, cost-effective, high-quality qualified personnel for the society.

\section{Acknowledgement}

This work is supported by the Science and Technology Department of Henan Province Soft

Science Project.A Study on the English Innovative Cultivation Mode from the Persprctive of Lingua-economics .project number: 152400410581.

\section{References}

[1] Ali B A A, Sapuan S M, Zainudin E S, et al. Implementation of the expert decision system for environmental assessment in composite materials selection for automotive components[J]. Journal of Cleaner Production, 2015.

[2] Babuska R, Verbruggon H B, Bancan H J L. Fuzzy modeling of enzymatic penicillin-G Anversion. Engineering Application of Artificial Intelligence, 1999, 12 (1): 79-72.

[3] Xiao W, Weidemann B. Fuzzy modeling and its application to magnetic bearing systems. Fuzzy Sets and Systems, 1995, 73(20): 20-217.

[4] Lee Chang Jun, Prasad Binay, Lee Jong Min. Stochastic nonlinear optimization for robust design of catalysts. Industrial and Engineering Chemistry Research, 2011, 50 (7): 3938-394.

[5] Y. Zhao, W. Wei, X.J. Tang, M.L. Zhao, Choice of Optimized Scheme Parameters of Neural Networks Based on Error Handling, AISS. 17(2012)76-82.

[6] Ho H P. The Influence of Braking System Component Design Parameters on Pedal Force and Displacement Characteristics. Simulation of a passenger car brake system, focusing on the prediction of brake pedal force and displacement based on the system components and their design characteristics[D]. University of Bradford, 2015.

[7] Diakaki C, Papageorgiou M, Papamichail I, et al. Overview and analysis of Vehicle Automation and Communication Systems from a motorway traffic management perspective[J]. Transportation Research Part A: Policy and Practice, 2015, 75: 147-165.

[8] Wang B, Huang X, Wang J, et al. A robust wheel slip ratio control design combining hydraulic and regenerative braking systems for in-wheel-motors-driven electric Vehicles[J]. Journal of the Franklin Institute, 2015, 352(2): 577-602.

[9] Reaidy P J, Gunasekaran A, Spalanzani A. Bottom-up approach based on internet of things for order fulfillment in a collaborative warehousing environment[J]. International Journal of Production Economics, 2015, 159: 29-40.

[10]Gonzalez E D R S, Sarkis J, Huisingh D, et al. Making real progress toward more sustainable societies using decision support models and tools: Introduction to the special volume[J]. Journal of Cleaner Production, 2015. 